medRxiv preprint doi: https://doi.org/10.1101/2022.02.08.22270608; this version posted February 10, 2022. The copyright holder for this preprint

(which was not certified by peer review) is the author/funder, who has granted medRxiv a license to display the preprint in perpetuity.

All rights reserved. No reuse allowed without permission.

History of Incarceration and Food Insecurity

\title{
Food Insecurity Among Older Adults with a History of Incarceration
}

Tamara Jordan, DO, MPH, MLS $;{ }^{1}$ Rodlescia Sneed, PhD, $\mathrm{MPH}^{1}$

${ }^{1}$ Division of Public Health, Michigan State University, Flint, MI

Corresponding Author: Dr. Tamara Jordan, DO, MPH, MLS; Michigan State University Division of Public Health; 200 East $1^{\text {st }}$ St., Flint, MI 48502, USA; 810-600-5658;

$\underline{\text { mill1612@msu.edu }}$ 
medRxiv preprint doi: https://doi.org/10.1101/2022.02.08.22270608; this version posted February 10, 2022. The copyright holder for this preprint (which was not certified by peer review) is the author/funder, who has granted medRxiv a license to display the preprint in perpetuity.

All rights reserved. No reuse allowed without permission.

History of Incarceration and Food Insecurity

\title{
Food Insecurity Among Older Adults with a History of Incarceration
}

\begin{abstract}
Objectives: To examine the association between history of incarceration (HOI) and food insecurity (FI) among older adults.

Methods: This is a secondary analysis utilizing data from 12,702 respondents aged 51+ who participated in the 2012 and 2014 waves of The Health and Retirement Study. Multiple logistic regression was used to estimate the association between HOI and FI, adjusting for demographic variables using odds ratios (OR) and $95 \%$ confidence intervals (CI).

Results: In our sample, $12.8 \%$ of participants reported FI. Having a HOI increased odds of FI (OR 1.83; 95\% CI 1.52-2.21), especially among Blacks (OR 1.78; 95\% CI 1.29-2.46) and Whites (OR 2.27; 95\% CI 1.74-2.97), but not Hispanics (OR 1.11; 95\% CI 0.69-1.77) or other racial/ethnic groups (OR 1.79; 95\% CI 0.71-4.52).
\end{abstract}

Discussion: FI is an important issue among older adults with a HOI. Stronger linkages between formerly incarcerated older adults and existing food assistance programs are needed.

Keywords: food insecurity, Health and Retirement Study, formerly incarcerated, older adults 
medRxiv preprint doi: https://doi.org/10.1101/2022.02.08.22270608; this version posted February 10, 2022. The copyright holder for this preprint

(which was not certified by peer review) is the author/funder, who has granted medRxiv a license to display the preprint in perpetuity.

All rights reserved. No reuse allowed without permission.

History of Incarceration and Food Insecurity

\section{Food Insecurity Among Older Adults with a History of Incarceration}

\section{Introduction}

Food insecurity (i.e., the inability to always access an appropriate quantity and quality of food to maintain an active and healthy lifestyle) is a growing problem among older adults. In the United States, about one in twelve adults aged 50 and older report being food insecure, which translates to over 9 million older adults (Gunderson \& Ziliak, 2021; Ziliak \& Gunderson, 2021). Numerous studies suggest that food insecurity among older adults can be attributed to chronic disease burden (Jih et al., 2018), functional limitations (Chang \& Hickman, 2018), and residing in multigenerational households (Ziliak \& Gunderson, 2016). Food insecurity is an important public health problem, as it is associated with greater risk of malnutrition and numerous chronic health conditions, including diabetes, high blood pressure, and depression (Gunderson \& Ziliak, 2015).

Older adults who have been previously incarcerated may be particularly at risk of food insecurity. There is a growing body of evidence suggesting that justice system involvement among older adults is rapidly increasing. From 1993 to 2013, the number of adults aged 55+ incarcerated in state prisons increased by $400 \%$, likely due to an increase in conviction rates among older adults and the use of longer prison sentences as a strategy to promote public safety (Carson \& Sabol, 2016). Additionally, there has been an increase in the number of older adults returning to community settings after incarceration, as states attempt to decarcerate older prisoners in an effort to reduce healthcare spending associated with caring for an older population (Williams \& Abraldes, 2007). Once released from prison, these older adults often face numerous challenges that increase their risk of food insecurity, including homelessness 
medRxiv preprint doi: https://doi.org/10.1101/2022.02.08.22270608; this version posted February 10, 2022. The copyright holder for this preprint (which was not certified by peer review) is the author/funder, who has granted medRxiv a license to display the preprint in perpetuity.

All rights reserved. No reuse allowed without permission.

History of Incarceration and Food Insecurity

(Couloute, 2018), as well as unemployment and poverty (Western \& Sirois, 2019). Several

studies conducted in younger samples suggest that incarceration is associated with increased risk of food insecurity (Testa \& Fahmy, 2021; Testa \& Jackson, 2019; Testa \& Jackson, 2020). These risk factors are likely magnified among older adults with a history of incarceration, as they likely also face age-related barriers to employment (e.g., age discrimination; Harootyan, 2021) and mobility issues (Bjelland et al., 2010), that further increase the risk of food insecurity.

Given that ninety-five percent of incarcerated individuals are eventually released (Hughes \& Wilson, 2003), and the rapid increase in justice system involvement among older adults, it is crucial to understand the health-related experiences of formerly incarcerated older adults after they reenter communities. While the association between previous incarceration and food insecurity has been explored in younger adults (Testa \& Fahmy, 2021; Testa \& Jackson, 2019; Testa \& Jackson, 2020), there has been little attention to food insecurity in older samples. Further, few studies have utilized population-based studies to examine this association. The purpose of this current study is to use a population-based sample of adults to examine the association between history of incarceration and food insecurity among community-dwelling older adults.

We were also interested in whether race/ethnicity moderated the association between history of incarceration and food insecurity. There are large racial/ethnic minority disparities in food insecurity. Nineteen percent of non-Hispanic Black households and 15.6\% of Hispanic households report food insecurity, compared to only $7.9 \%$ of non-Hispanic White households (Coleman-Jensen et al., 2020). Additionally, racial/ethnic minorities are more likely to be incarcerated than non-Hispanic White Americans. While non-Hispanic Blacks make up only $13.4 \%$ of the U.S. population (U.S. Census Bureau, 2019), they account for $38.1 \%$ of those 
medRxiv preprint doi: https://doi.org/10.1101/2022.02.08.22270608; this version posted February 10, 2022. The copyright holder for this preprint (which was not certified by peer review) is the author/funder, who has granted medRxiv a license to display the preprint in perpetuity. All rights reserved. No reuse allowed without permission.

History of Incarceration and Food Insecurity

currently incarcerated (Federal Bureau of Prisons, 2022). Likewise, Hispanics make up 18.5\% of the total U.S. population (U.S. Census Bureau, 2019), but account for $30.4 \%$ of those currently incarcerated (Federal Bureau of Prisons, 2022). Given these data, we would expect that nonHispanic Blacks and Hispanics with a history of incarceration would be at even greater risk of food insecurity.

Finally, we explored factors that might mediate the association between history of incarceration and food insecurity. Several studies demonstrate that poverty is a predictor of food insecurity. According to the U.S. Department of Agriculture, about 29\% of households under $185 \%$ of the federal poverty level were found to be food insecure in 2020 , compared to only about $5 \%$ of households with incomes at $185 \%$ of the federal poverty level and above (ColemanJensen et al., 2021). Likewise, studies by Goldberg \& Mawn (2015) and Morrissey et al. (2016) found that as poverty level increases, the likelihood of experiencing food insecurity also increases. Employment status, intricately linked to income, has also been associated with food insecurity. Coleman-Jensen (2011) found that households with heads who were unemployed, working part-time, or held multiple jobs, had greater odds of being food insecure than households with heads working one full-time job. Likewise, a multinational study conducted by Reeves et al. (2021) found a high predicted probability for moderate to severe food insecurity among the unemployed. Similarly, Huang et al. (2015) found that those who were unemployed had 55\% increased odds of being food insecure. Given these known linkages between poverty, unemployment, and food insecurity, we tested the assumption that income level and employment status would mediate the association between history of incarceration and food insecurity. To address our research questions, we used cross-sectional data from the Health and Retirement Study, a population-based survey of community-dwelling U.S. older adults aged $>50$. 
medRxiv preprint doi: https://doi.org/10.1101/2022.02.08.22270608; this version posted February 10, 2022. The copyright holder for this preprint

(which was not certified by peer review) is the author/funder, who has granted medRxiv a license to display the preprint in perpetuity.

All rights reserved. No reuse allowed without permission.

History of Incarceration and Food Insecurity

\section{Methods}

\section{Study Design}

This is a cross-sectional analysis pooling de-identified, publicly available survey data from the 2012 and 2014 waves of the Health and Retirement Study (HRS), an ongoing national longitudinal study of adults 51 and older (Heeringa \& Connor, 1995). The HRS uses a four-stage probability sampling design to recruit adults aged 51 and older into the longitudinal study, oversampling non-Hispanic Blacks, Hispanics, and Florida residents, details of which are described elsewhere (Heeringa \& Connor, 1995). Spouses of selected individuals are enrolled as well, regardless of age. During each wave of the HRS, surveyors collect data on a variety of demographic, lifestyle, health, biological, psychosocial, and physical measures. This current study was exempt from Michigan State University IRB review (STUDY00006614).

\section{Assessment of Incarceration History}

History of incarceration was assessed via self-report in the 2012 and 2014 waves of the HRS. The item measuring history of incarceration was included in the psychosocial leave behind questionnaire, which is administered to a random $50 \%$ of all HRS respondents. Fifty percent of HRS respondents received the psychosocial leave behind questionnaire in 2012 and the other $50 \%$ of respondents received the questionnaire in 2014. Participants were asked if they had previously been inmates in a jail or prison (yes/no).

\section{Covariates}

We adjusted for the following variables in our analyses: marital status (married, partnered, separated or divorced, widowed, never married), race/ethnicity (non-Hispanic White, non-Hispanic Black, non-Hispanic Other, Hispanic), gender (male/female), age (continuous variable), income (continuous variable), labor force status (working full-time, working part-time, 
medRxiv preprint doi: https://doi.org/10.1101/2022.02.08.22270608; this version posted February 10, 2022. The copyright holder for this preprint

(which was not certified by peer review) is the author/funder, who has granted medRxiv a license to display the preprint in perpetuity.

All rights reserved. No reuse allowed without permission.

History of Incarceration and Food Insecurity

unemployed, partly retired, retired, disabled, not in labor force), education (less than high school, GED, high school graduate, some college, college and above), and mother's years of education (continuous variable). All categorical variables were dummy coded.

\section{Assessment of Food Insecurity}

During the 2012 and 2014 waves of the HRS, one member of each household was asked the following question on behalf of the entire household: "In the last two years, did you ever not have enough money to buy the food you need (yes/no)?” Households were considered food insecure if the household respondent responded "yes" to this question.

\section{Sample Size}

A total of 14,460 individuals completed the 2012 and 2014 HRS psychosocial leave behind questionnaires. We excluded 415 individuals who were 50 years of age and younger, another 104 individuals who did not respond to the questions about food insecurity and history of incarceration, and an additional 1,239 individuals missing data on any of the covariates. The final sample included 12,702 participants ages 51 and older.

Analysis

We used multiple logistic regression to evaluate the association between history of incarceration and household food insecurity, adjusting for age, race/ethnicity, gender, education, marital status, employment status, and mother's years of education. Associations were assessed using odds ratios (ORs) and 95\% confidence intervals (CIs).

To evaluate differences in the association between incarceration and food insecurity based on race/ethnicity, we performed stratified analyses by racial/ethnic group. We calculated ORs and 95\% CIs, adjusting for age, education, gender, marital status, and mother's years of education. To test whether income level and/or employment status mediated the association 
medRxiv preprint doi: https://doi.org/10.1101/2022.02.08.22270608; this version posted February 10, 2022. The copyright holder for this preprint (which was not certified by peer review) is the author/funder, who has granted medRxiv a license to display the preprint in perpetuity.

All rights reserved. No reuse allowed without permission.

History of Incarceration and Food Insecurity

between history of incarceration, we evaluated the association between history of incarceration and income using linear regression and between history of incarceration and employment using chi-squared analysis. We added each variable separately to our main logistical regression model evaluating the association between history of incarceration and food insecurity, adjusting for our standard covariates. Variables were considered potential mediators if they significantly reduced the association between history of incarceration and food insecurity in our model. All quantitative analyses were conducted using IBM SPSS Statistics (IBM, n.d.).

\section{Results}

Our final sample included 12,702 respondents. The mean age of the sample was 68.4 (SD 10.3 ) and $59 \%$ of respondents were female (Table 1). Of the total sample, $71.1 \%$ of respondents were non-Hispanic White, 15.2\% were non-Hispanic Black, 10.9\% were Hispanic and 2.8\% were of other racial/ethnic backgrounds. Sixty percent of respondents were married, and $85.8 \%$ had at least a high school education or equivalent. Fifty-seven percent of respondents were retired, and twenty-three percent were working full-time. Of the total sample, $12.8 \%$ reported food insecurity. 
medRxiv preprint doi: https://doi.org/10.1101/2022.02.08.22270608; this version posted February 10, 2022. The copyright holder for this preprint (which was not certified by peer review) is the author/funder, who has granted medRxiv a license to display the preprint in perpetuity.

All rights reserved. No reuse allowed without permission.

History of Incarceration and Food Insecurity

Table 1

Characteristics of Study Population ( $n=12,702)$

\begin{tabular}{|c|c|c|c|c|}
\hline \multirow{2}{*}{ Variable } & \multirow{2}{*}{ Overall } & \multicolumn{2}{|c|}{ History of Incarceration } & \multirow{2}{*}{ p-value } \\
\hline & & Yes & No & \\
\hline \% Food Insecure & 12.8 & 27.6 & 11.7 & $<.001$ \\
\hline Gender & & & & $<.001$ \\
\hline$\%$ Female & 59.4 & 21.5 & 62.2 & \\
\hline$\%$ Male & 40.6 & 78.5 & 37.8 & \\
\hline Race/Ethnicity & & & & $<.001$ \\
\hline$\%$ non-Hispanic White & 71.1 & 53.8 & 72.4 & \\
\hline$\%$ non-Hispanic Black & 15.2 & 28.6 & 14.2 & \\
\hline$\%$ non-Hispanic Other & 2.8 & 3.8 & 2.8 & \\
\hline$\%$ Hispanic & 10.9 & 13.9 & 10.7 & \\
\hline Marital Status & & & & $<.001$ \\
\hline$\%$ Married & 60.2 & 51.2 & 60.8 & \\
\hline$\%$ Partnered & 4.6 & 13.0 & 3.9 & \\
\hline$\%$ Separated or Divorced & 13.1 & 21.4 & 12.5 & \\
\hline$\%$ Widowed & 17.8 & 6.9 & 18.6 & \\
\hline$\%$ Never Married & 4.4 & 7.5 & 4.1 & \\
\hline Education & & & & $<.001$ \\
\hline$\%$ Less Than High School & 14.2 & 21.6 & 13.6 & \\
\hline$\%$ GED & 4.8 & 11.3 & 4.4 & \\
\hline \% High School Graduate & 29.5 & 23.4 & 29.9 & \\
\hline$\%$ Some College & 26.1 & 29.2 & 25.9 & \\
\hline$\%$ College and Above & 25.4 & 14.4 & 26.2 & \\
\hline Employment Status & & & & $<.001$ \\
\hline$\%$ Works Full-Time & 22.9 & 26.6 & 22.6 & \\
\hline$\%$ Works Part-Time & 4.9 & 5.2 & 4.9 & \\
\hline \% Unemployed & 2.3 & 5.5 & 2.1 & \\
\hline$\%$ Partially Retired & 8.4 & 6.8 & 8.5 & \\
\hline$\%$ Retired & 56.7 & 50.9 & 57.1 & \\
\hline \% Disabled & 1.5 & 3.1 & 1.4 & \\
\hline$\%$ Not in Labor Force & 3.3 & 1.9 & 3.4 & \\
\hline $\begin{array}{l}\text { Mean Mother's Years Education } \\
\text { (SD) }\end{array}$ & $10.0(3.7)$ & $9.8(3.9)$ & $10.0(3.7)$ & .088 \\
\hline Mean Age, Years (SD) & $68.4(10.3)$ & $63.4(8.7)$ & $68.8(10.3)$ & $<.001$ \\
\hline $\begin{array}{c}\text { Mean Annual Income, U.S. } \\
\text { Dollars (SD) }\end{array}$ & $\begin{array}{c}16,206.50 \\
(41,632.80)\end{array}$ & $\begin{array}{c}13,693.29 \\
(29,513.04)\end{array}$ & $\begin{array}{c}16,393.35 \\
(42,390.70)\end{array}$ & .064 \\
\hline
\end{tabular}

When entered into the logistic regression model simultaneously, the following covariates were related to increased risk of food insecurity: female gender ( $\mathrm{OR}=1.25$; 95\% CI: 1.10-1.42); nonHispanic Black race/ethnicity (compared to non-Hispanic Whites; (OR=2.56; 95\% CI: 2.23-2.94)); Hispanic ethnicity (OR=1.94; 95\% CI: 1.62-2.34); other racial/ethnic group status ( $O R=1.74 ; 95 \%$ CI: 1.28-2.36); being partnered (compared to being married ( $\mathrm{OR}=1.97 ; 95 \% \mathrm{CI}: 1.56-2.48)$ ); being separated or divorced ( $\mathrm{OR}=2.56$; $95 \% \mathrm{CI}: 2.21-2.97)$; being widowed $(\mathrm{OR}=1.97 ; 95 \% \mathrm{CI}: 1.65-$ 
medRxiv preprint doi: https://doi.org/10.1101/2022.02.08.22270608; this version posted February 10, 2022. The copyright holder for this preprint (which was not certified by peer review) is the author/funder, who has granted medRxiv a license to display the preprint in perpetuity.

All rights reserved. No reuse allowed without permission.

History of Incarceration and Food Insecurity

2.34); never being married ( $\mathrm{OR}=2.38$; $95 \% \mathrm{CI}$ : 1.90-2.99); having left high school (compared to those with at least a college degree; $(\mathrm{OR}=2.98$; 95\% CI: 2.41-3.67)); having a GED (OR=2.53; 95\%

CI: 1.94-3.28); being a high school graduate (OR=2.01; 95\% CI: 1.68-2.41); and having some college (OR=1.56; 95\% CI: 1.25-1.81). The following covariates were associated with decreased risk of food insecurity: older age $(\mathrm{OR}=0.94$; $95 \% \mathrm{CI}$ : 0.94-0.95) and mother's years of education $(\mathrm{OR}=$ 0.97; 95\% CI: 0.95-0.99).

Seven percent $(n=879)$ of respondents reported a history of incarceration. In a logistic regression model including all the covariates, we found that history of incarceration was associated with increased odds of food insecurity. After adjusting for education, gender, race/ethnicity, marital status, mother's educational years, and age, those with a history of incarceration showed 83\% increased odds (OR 1.83; 95\% CI 1.52-2.21) of being food insecure compared to those without a history of incarceration (Figure 1).

Figure 1: Odds of Reporting Food Insecurity

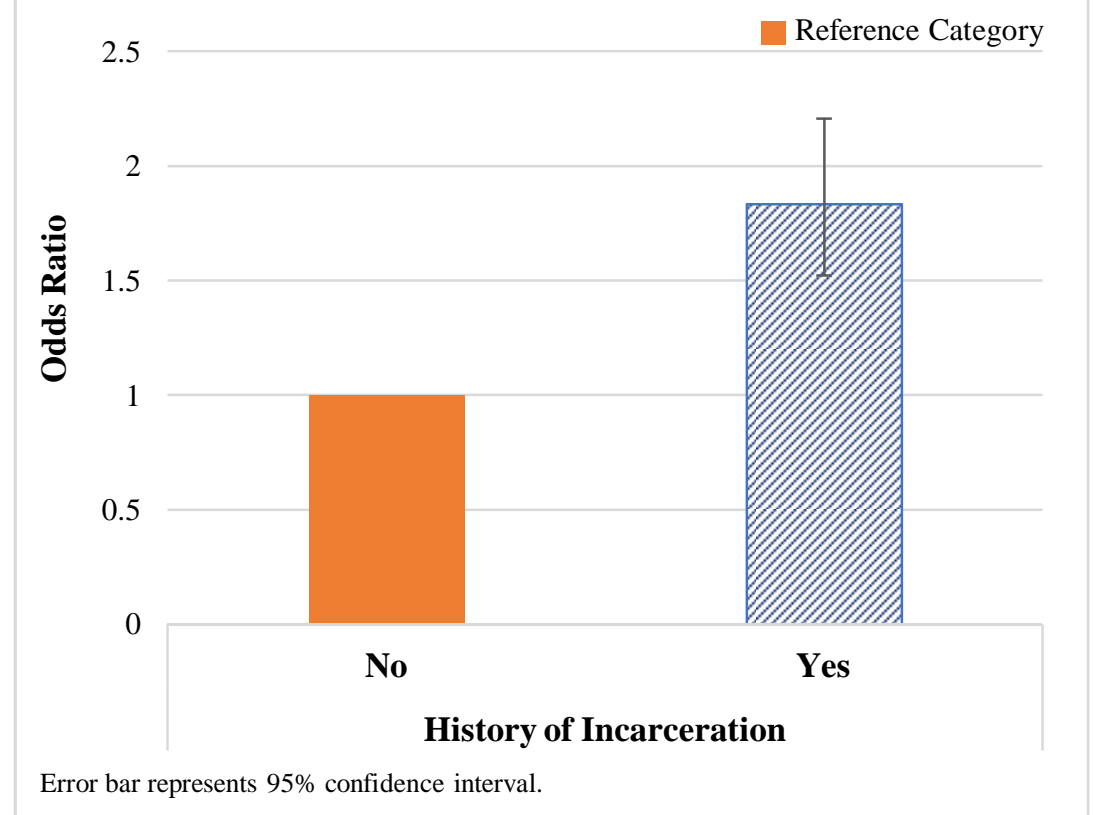

Separate logistic regression models were constructed to assess food insecurity among each racial/ethnic group, comparing those with a history of incarceration to those without a 
medRxiv preprint doi: https://doi.org/10.1101/2022.02.08.22270608; this version posted February 10, 2022. The copyright holder for this preprint (which was not certified by peer review) is the author/funder, who has granted medRxiv a license to display the preprint in perpetuity. All rights reserved. No reuse allowed without permission.

History of Incarceration and Food Insecurity

history of incarceration. All models were adjusted for education, gender, marital status, mother's educational years, and age. Compared to non-Hispanic Whites without a history of incarceration, non-Hispanic Whites with a history of incarceration had $127 \%$ increased odds (OR 2.27; 95\% CI 1.74-2.97) of food insecurity (Figure 2). Compared to non-Hispanic Blacks without a history of incarceration, non-Hispanic Blacks with a history of incarceration had $78 \%$ increased odds (OR 1.78; 95\% CI 1.29-2.46) of food insecurity. There was no significant association between history of incarceration and food insecurity among Hispanics (OR 1.11; 95\% CI 0.69-1.77) or nonHispanics of other backgrounds (OR 1.79; 95\% CI 0.71-4.52).

Figure 2: Odds of Reporting Food Insecurity by Race/Ethnicity and History of Incarceration

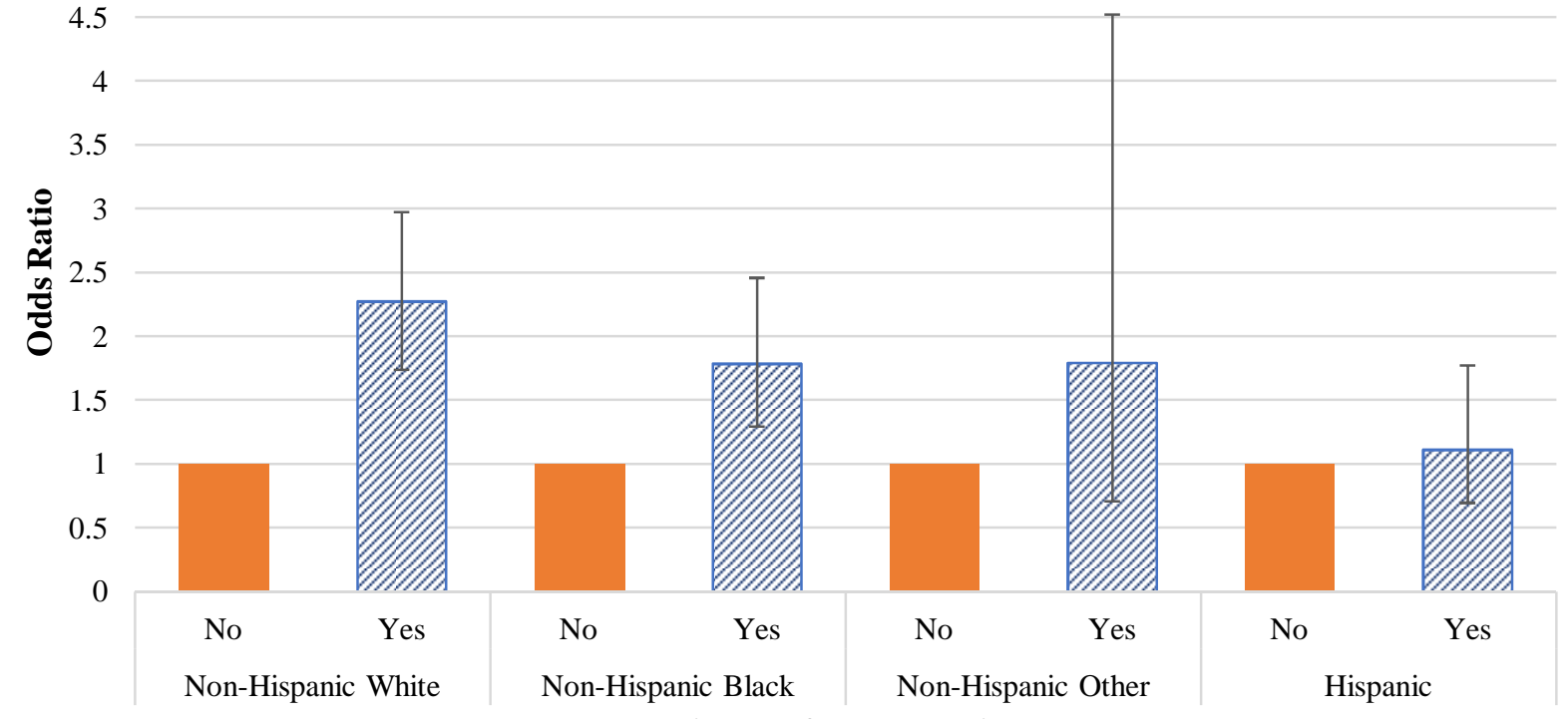

Error bars represent $95 \%$ confidence intervals.

History of Incarceration

Finally, we were interested in whether respondent employment status and income mediated the association between history of incarceration and food insecurity. We observed that history of incarceration was associated with both income $(\beta=-.038 ; \mathrm{p}<.001)$ and employment status $\left(\square^{2}(6, \mathrm{~N}=12702)=77.16, \mathrm{p}<.001\right)$. However, the association between history of 
medRxiv preprint doi: https://doi.org/10.1101/2022.02.08.22270608; this version posted February 10, 2022. The copyright holder for this preprint

(which was not certified by peer review) is the author/funder, who has granted medRxiv a license to display the preprint in perpetuity.

All rights reserved. No reuse allowed without permission.

History of Incarceration and Food Insecurity

incarceration and food insecurity was not reduced when adding income or employment status to our logistic regression model.

\section{Discussion}

This study examined the association between history of incarceration and household food insecurity among U.S. community-dwelling older adults. We found that older adults with a history of incarceration had $83 \%$ increased odds of household food insecurity compared to those without a history of incarceration. This was true even after adjusting for potential confounding factors. The findings from this study are consistent with findings from studies of households with young children (Cox \& Wallace, 2016), recently incarcerated new parents (Testa \& Fahmy, 2021), and young adults (Testa \& Jackson, 2019).

We also evaluated whether race/ethnicity moderated the association between history of incarceration and food insecurity. We found that there was an association between history of incarceration and food insecurity among non-Hispanic Whites and non-Hispanic Blacks, but not among Hispanics or those of other racial backgrounds. One possible explanation is that Hispanics and non-Hispanics of other racial groups tend to have larger household sizes than nonHispanic Whites and non-Hispanic Blacks (U.S. Census Bureau, 2016). More importantly, Hispanics and non-Hispanics of other racial groups tend to have more people ages $18+$ within the household (U.S. Census Bureau, 2016). Having more adults in the household may increase household economic resources in ways that decrease risk of food insecurity among Hispanics and other non-Hispanic groups.

It is also possible that racial/ethnic differences in food sources account for differences in food insecurity. Hispanic families are more likely than non-Hispanics to utilize WIC program services (Quandt et al., 2004; Sharkey et al., 2013). Non-Hispanic Blacks (Zekeri, 2007) and 
medRxiv preprint doi: https://doi.org/10.1101/2022.02.08.22270608; this version posted February 10, 2022. The copyright holder for this preprint (which was not certified by peer review) is the author/funder, who has granted medRxiv a license to display the preprint in perpetuity. All rights reserved. No reuse allowed without permission.

History of Incarceration and Food Insecurity

Hispanics (Kaufman \& Karpati, 2007) report stigma as a factor when considering enrollment in food stamps programs. However, this does not seem to be a true barrier to enrollment for Hispanics (Kaufman \& Karpati, 2007). Hispanics also rely heavily on social networks to cope with food insecurity, such as grandmothers and relationships with local bodega owners (Kaufman \& Karpati, 2007). Given the limitations of the HRS data, we were unable to test these hypotheses. Future studies should consider how enrollment in supplemental food programs and social networks might mediate the association between incarceration history and food insecurity.

Additionally, differences in the amount of time spent incarcerated may explain racial/ethnic differences in the association between food insecurity and incarceration. In a previous study, Jordan \& Freiburger (2015) found that Hispanics receive shorter sentences than non-Hispanic Whites and non-Hispanic Blacks. Additionally, Hispanics have been found to be released on parole more quickly than non-Hispanic Whites and non-Hispanic Blacks (Huebner \& Bynum, 2008). To the authors' knowledge, no studies have been conducted to identify the association between length of incarceration and food insecurity. Shorter length of incarceration may increase prospects for employment in ways that reduce food insecurity. Due to lack of efficient data on length of incarceration available in the HRS, we were unable to evaluate this association in the current study. Future studies should focus on identifying this association between length of incarceration and food insecurity.

Based on previous studies identifying an association between income and employment and food insecurity, we also evaluated whether income and employment mediated the relationship between history of incarceration and food insecurity. Although both income and employment status were associated with incarceration, neither of them reduced the association 
medRxiv preprint doi: https://doi.org/10.1101/2022.02.08.22270608; this version posted February 10, 2022. The copyright holder for this preprint

(which was not certified by peer review) is the author/funder, who has granted medRxiv a license to display the preprint in perpetuity.

All rights reserved. No reuse allowed without permission.

History of Incarceration and Food Insecurity

between history of incarceration and food insecurity. Future studies should explore other factors that might mediate the association between prior incarceration and food insecurity.

This study has several strengths. First, it utilized a large population-based sample of community-dwelling older adults with an oversampling of non-Hispanic Blacks and Hispanics.

This is important, as previous studies have demonstrated that non-Hispanic Blacks and Hispanics experience high rates of incarceration (Carson, 2020). However, many studies regarding food insecurity among older adults tend to include fewer non-White participants (Afulani et al., 2015) or do not delineate race/ethnicity at all (Grammatikopoulou et al., 2019). Additionally, the HRS includes comprehensive demographic and economic data, which allowed us to explore these factors as other possible determinants of food insecurity.

This study is not without limitations. Due to the cross-sectional nature of this study, causality cannot be inferred. Additionally, we did not have data on length of incarceration, which may moderate the association between incarceration and food insecurity or explain observed racial ethnic/differences. Also, due to the secondary nature of this study, variables were limited to what was available from the primary data. Despite these limitations, to the authors'

knowledge, this is the first study that describes the association between food insecurity and history of incarceration using a population-based sample of older adults.

Our work has important implications for health policy and health promotion activities. There are numerous food assistance programs available to community-dwelling older adults, including The Supplemental Nutrition Assistance Program (SNAP; Food and Nutrition Service, n.d.a), Meals on Wheels (Meals on Wheels America, n.d.), The Commodity Supplemental Food Program (Food and Nutrition Service, n.d.b), The Senior Farmers' Market Nutrition Program (Food and Nutrition Service, n.d.c), and The Emergency Food Assistance Program (Food and 
medRxiv preprint doi: https://doi.org/10.1101/2022.02.08.22270608; this version posted February 10, 2022. The copyright holder for this preprint

(which was not certified by peer review) is the author/funder, who has granted medRxiv a license to display the preprint in perpetuity.

All rights reserved. No reuse allowed without permission.

History of Incarceration and Food Insecurity

Nutrition, n.d.d). In some states, however, some of these programs have eligibility restrictions that may exclude certain individuals (i.e., those with felony drug convictions) from participation (Wolkomir, 2018). Current and future food assistance social service programs and interventions should be developed and implemented to include older adults with a history of incarceration.

Steps should also be taken to ensure that formerly incarcerated older adults are being connected with these programs as well. Additionally, due to current policy restrictions, formerly incarcerated individuals face a plethora of collateral consequences that may also contribute to food insecurity, such as difficulty finding stable employment (Welsh, 2015) and stable housing (Geller \& Curtis, 2011). System policies such as these should be re-examined and implemented such that this population is no longer being excluded. Future studies should be conducted to build upon the results of this study as well as to further contribute to the current literature that is sorely lacking in this subject area.

Declaration of Conflicting Interests: The authors declare that there is no conflict of interest.

Funding: This project was funded by Michigan Center for Urban African-American Aging Center through a grant from the National Institutes of Health (grant number P30 AG015281).

Acknowledgments: This analysis uses data from the Health and Retirement Study (2012 HRS

Core, 2014 HRS Core, and RAND HRS Longitudinal File 2018), sponsored by the National Institute on Aging (grant number NIA U01AG009740) and conducted by the University of Michigan. 
medRxiv preprint doi: https://doi.org/10.1101/2022.02.08.22270608; this version posted February 10, 2022. The copyright holder for this preprint

(which was not certified by peer review) is the author/funder, who has granted medRxiv a license to display the preprint in perpetuity.

All rights reserved. No reuse allowed without permission.

History of Incarceration and Food Insecurity

\section{References}

Afulani, P., Herman, D., Coleman-Jensen, A., \& Harrison, G.G. (2015). Food insecurity and health outcomes among older adults: The role of cost-related medication underuse. Journal of Nutrition in Gerontology and Geriatrics, 34(3), 319-342. Doi: $10.1080 / 21551197.2015 .1054575$

Bjelland, M.J., Bruyere, S.M., von Shrader, S., Houtenville, A.J., Ruiz-Quintanilla, A., \& Webber, D.A. (2010). Age and disability employment discrimination: Occupational rehabilitation implications. Journal of Occupational Rehabilitation, 20(4), 456-471. Doi:

\section{$\underline{10.1007 / \mathrm{s} 10926-009-9194-\mathrm{Z}}$}

Carson, E.A. (2020). Prisoners in 2019. U.S. Department of Justice - Office of Justice Programs.

\section{https://bjs.ojp.gov/content/pub/pdf/p19.pdf}

Carson, E.A. \& Sabol, W.J. (2016). Aging of the state prison population. U.S. Department of Justice - Office of Justice Programs. https://bjs.ojp.gov/content/pub/pdf/aspp9313.pdf

Chang, Y. \& Hickman, H. (2018). Food insecurity and perceived diet quality among low-income older Americans with functional limitations. Journal of Nutrition Education and Behavior, 50(5), 476-484. Doi: 10.1016/j.jneb.2017.09.006

Coleman-Jensen, A.J. (2011). Working for peanuts: Nonstandard work and food insecurity across household structure. Journal of Family and Economic Issues, 32, 84-97. Doi:

\section{$\underline{10.1007 / \mathrm{s} 10834-010-9190-7}$}

Coleman-Jensen, A., Rabbitt, M.P., Gregory, C.A., \& Singh, A. (2020). Household food security in the United States in 2019. U.S. Department of Agriculture. https://www.ers.usda.gov/webdocs/publications/99282/err-275.pdf?v=8761.4 
medRxiv preprint doi: https://doi.org/10.1101/2022.02.08.22270608; this version posted February 10, 2022. The copyright holder for this preprint (which was not certified by peer review) is the author/funder, who has granted medRxiv a license to display the preprint in perpetuity.

All rights reserved. No reuse allowed without permission.

History of Incarceration and Food Insecurity

Coleman-Jensen, A., Rabbitt, M.P., Hales, L., \& Gregory, C.A. (2021). Food security in the U.S.: Key statistics \& graphics. U.S. Department of Agriculture. https://www.ers.usda.gov/topics/food-nutrition-assistance/food-security-in-the-u-s/keystatistics-graphics/\#householdtype

Couloute, L. (2018). Nowhere to go: Homelessness among formerly incarcerated people. Prison Policy Initiative. https://www.jstor.org/stable/pdf/resrep27306.pdf?acceptTC=true\&coverpage=false \&add $\underline{\text { Footer }=\text { false }}$

Cox, R. \& Wallace, S. (2016). Identifying the link between food security and incarceration. Southern Economic Journal, 82(4), 1062-1077). Doi: 10.1002/soej.12080

Federal Bureau of Prisons. (2022). Inmate Statistics. https://www.bop.gov/about/statistics/statistics_inmate_age.jsp

Food and Nutrition Service. (n.d.a). Supplemental Nutrition Assistance Program (SNAP). U.S. Department of Agriculture. https://www.fns.usda.gov/snap/supplemental-nutrition$\underline{\text { assistance-program }}$

Food and Nutrition Service. (n.d.b). Commodity Supplemental Food Program. U.S. Department of Agriculture. https://www.fns.usda.gov/csfp/commodity-supplemental-food-program

Food and Nutrition Service. (n.d.c). Seniors Farmers' Market Nutrition Program. U.S. Department of Agriculture. https://www.fns.usda.gov/sfmnp/senior-farmers-marketnutrition-program

Food and Nutrition Service. (n.d.d). The Emergency Food Assistance Program. U.S. Department of Agriculture. https://www.fns.usda.gov/tefap/emergency-food-assistance-program 
medRxiv preprint doi: https://doi.org/10.1101/2022.02.08.22270608; this version posted February 10, 2022. The copyright holder for this preprint (which was not certified by peer review) is the author/funder, who has granted medRxiv a license to display the preprint in perpetuity. All rights reserved. No reuse allowed without permission.

History of Incarceration and Food Insecurity

Geller, A. \& Curtis, M.A. (2011). A sort of homecoming: Incarceration and the housing security of urban men. Social Science Research, 40(4), 1196-1213. Doi:

\subsection{6/j.ssresearch.2011.03.008}

Goldberg, S.L. \& Mawn, B.E. (2015). Predictors of food insecurity among older adults in the United States. Public Health Nursing, 32(5), 397-407. Doi: 10.1111/phn.12173

Grammatikopoulou, M.G., Gkiouras, K., Theodoridis, X., Tsisimiri, M., Markaki, A.G., Chourdakis, M., \& Goulis, D.G. (2019). Food insecurity increases the risk of malnutrition among community-dwelling older adults. Maturitas, 119, 8-13. Doi:

10.1016/j.maturitas.2018.10.009

Gunderson, C. \& Ziliak, J.P. (2015). Food insecurity and health outcomes. Health Affairs, 34(11), 1830-1839. Doi: 10.1377/hlthaff.2015.0645

Gunderson, C. \& Ziliak, J.P. (2021). Hunger among adults age 50-59 in 2019: An annual report. Feeding America. https://www.feedingamerica.org/sites/default/files/2021-08/2021\%20\%20Hunger\%20Among\%20Adults\%2050-59\%202019.pdf

Harootyan, B. (2021). Hidden dimensions of ageism in employment and the weakening of the Age Discrimination in Employment Act. Public Policy \& Aging Report, 31(4), 129-132. Doi: $10.1093 /$ ppar/prab020

Heeringa, S.G. \& Connor, J.H. (1995). Technical description of the Health and Retirement Survey sample design. Institute for Social Research, University of Michigan, Ann Arbor, MI. https://hrs.isr.umich.edu/sites/default/files/biblio/HRSSAMP.pdf

Huang, J., Kim, Y., \& Birkenmaier, J. (2015). Unemployment and household food hardship in the economic recession. Public Health Nutrition, 19(3), 511-519. Doi:

10.1017/S1368980015001603 
medRxiv preprint doi: https://doi.org/10.1101/2022.02.08.22270608; this version posted February 10, 2022. The copyright holder for this preprint (which was not certified by peer review) is the author/funder, who has granted medRxiv a license to display the preprint in perpetuity. All rights reserved. No reuse allowed without permission.

History of Incarceration and Food Insecurity

Huebner, B.M. \& Bynum, T.S. (2008). The role of race and ethnicity in parole decisions. Criminology, 46(4), 907-938. Doi: 10.1111/j.1745-9125.2008.00130.x

Hughes, T. \& Wilson, D.J. (2003). Reentry trends in the United States. Bureau of Justice Statistics. https://bjs.ojp.gov/content/pub/pdf/reentry.pdf

IBM. (n.d.). Analytics: IBM SPSS trials. https://www.ibm.com/analytics/spss-trials

Jih, J., Stijacic-Cenzer, I., Seligman, H.K., Boscardin, W.J., Nguyen, T.T., \& Ritchie, C.S. (2018). Chronic disease burden predicts food insecurity among older adults. Public Health Nutrition, 21(9), 1737-1742. Doi: 10.1017/S1368980017004062

Jordan, K.L. \& Freiburger, T.L. (2015). The effect of race/ethnicity on sentencing: Examining sentence type, jail length, and prison length. Journal of Ethnicity in Criminal Justice, 13(3), 179-196. Doi: 10.1080/15377938.2014.984045

Kaufman, L. \& Karpati, A. (2007). Understanding the sociocultural roots of childhood obesity: Food practices among Latino families of Bushwick, Brooklyn. Social Science \& Medicine, 64(11), 2177-2188. Doi: 10.1016/j.socscimed.2007.02.019

Meals on Wheels America. (n.d.). https://www.mealsonwheelsamerica.org/learn-more/national Morrissey, T.W., Oellerich, D., Meade, E., Simms, J., \& Stock, A. (2016). Neighborhood poverty and children's food insecurity. Children and Youth Services Review, 66, 85-93. Doi: 10.1016/j.childyouth.2016.05.006

Quandt, S.A., Arcury, T.A., Early, J., Tapia, J., \& Davis, J.D. (2004). Household food security among migrant and seasonal Latino farmworkers in North Carolina. Public Health Reports, 119(6), 568-576. Doi: 10.1016/j.phr.2004.09.006 
medRxiv preprint doi: https://doi.org/10.1101/2022.02.08.22270608; this version posted February 10, 2022. The copyright holder for this preprint (which was not certified by peer review) is the author/funder, who has granted medRxiv a license to display the preprint in perpetuity. All rights reserved. No reuse allowed without permission.

History of Incarceration and Food Insecurity

Reeves, A., Loopstra, R., \& Tarasuk, V. (2021). Wage-setting policies, employment, and food insecurity: A multilevel analysis of 492078 people in 139 countries. American Journal of Public Health, 111, 718-725. Doi: 10.2105/AJPH.2020.306096

Sharkey, J.R., Dean, W.R., \& Nalty, C.C. (2013). Child hunger and the protective effects of Supplemental Nutrition Assistance Program (SNAP) and alternative food sources among Mexican-origin families in Texas border colonias. BMC Pediatrics, 13(143). Doi:

$10.1186 / 1471-2431-13-143$

Testa, A. \& Fahmy, C. (2021). Incarceration exposure and food insecurity during pregnancy: Investigating the moderating role of social support. Journal of Criminal Justice, 73, 101793. Doi: 10.1016/j.jcrimjus.2021.101793

Testa, A. \& Jackson, D.B. (2019). Food insecurity among formerly incarcerated adults. Criminal Justice and Behavior, 46(10), 1493-1511. Doi: 10.1177/0093854819856920

Testa, A. \& Jackson, D.B. (2020). Criminal justice system involvement and food insufficiency: Findings from the 2018 New York City Community Health Survey. Annals of Epidemiology, 52, 42-45. Doi: 10.1016/j.annepidem.2020.08.064

U.S. Census Bureau. (2016). Table AVG1. Average number of people per household, by race and Hispanic origin, marital status, age, and education of householder: 2016. https://www.census.gov/data/tables/2016/demo/families/cps-2016.html

U.S. Census Bureau. (2019). QuickFacts: United States. https://www.census.gov/quickfacts/fact/table/US/PST045221

Welsh, M. (2015). Categories of exclusion: The transformation of formerly incarcerated women into "able-bodied adults without dependents" in welfare processing. Journal of Sociology \& Social Welfare, 42(2), 55-78. 
medRxiv preprint doi: https://doi.org/10.1101/2022.02.08.22270608; this version posted February 10, 2022. The copyright holder for this preprint (which was not certified by peer review) is the author/funder, who has granted medRxiv a license to display the preprint in perpetuity. All rights reserved. No reuse allowed without permission.

History of Incarceration and Food Insecurity

Western, B. \& Sirois, C. (2019). Racialized re-entry: Labor market inequality after incarceration. Social Forces, 97(4), 1517-1542. Doi: 10.1093/sf/soy096

Williams, B. \& Abraldes, R. (2007). Chapter 5 - Growing older: Challenges of prison and reentry for the aging population. In R. Greifinger (Ed.), Public health behind bars: From prisons to communities (pp. 56-72). Springer. Doi: 10.1007/978-0-387-71695-4_5

Wolkomir, E. (2018). How SNAP can better serve the formerly incarcerated. Center on Budget and Policy Priorities. https://www.cbpp.org/sites/default/files/atoms/files/3-6-18fa.pdf

Zekeri, A.A. (2007). Livelihood strategies of food-insecure poor, female-headed families in rural Alabama. Psychological Reports, 101(3 suppl), 1031-1036. Doi: 10.2466/pr0.101.4.1031$\underline{1036}$

Ziliak, J.P. \& Gunderson, C. (2016). Multigenerational families and food insecurity. Southern Economic Journal, 82(4), 1147-1166. Doi: 10.1002/soej.12082

Ziliak, J. \& Gunderson, C. (2021). The state of senior hunger in America in 2019: An annual report. Feeding America. https://www.feedingamerica.org/sites/default/files/202108/2021\%20-\%20State\%20of\%20Senior\%20Hunger\%20in\%202019.pdf 